\title{
Методы трансформации цианобактерий и их применение
}

Кувырченкова А.П.

Национальный исследовательский иентр «Курчатовский институт», Москва, Россия

*kuvyrchenkova@phystech.edu

Ключевые слова: геномное редактирование, цианобактерия, штамм-продуцент

Мотиваџия и цุель: Цианобактерии - это единственные бактерии, способные осуществлять кислородный фотосинтез. Для жизни им требуется лишь солнечный свет, $\mathrm{CO}_{2}$ и неорганические элементы, что делает цианобактерии популярными объектами для создания штаммов-продуцентов. Их применение для производства промышленно важных продуктов является наиболее экологически чистым, а использование их вместо растений позволяет снизить требования к земле и снижает конкуренцию с продовольственными культурами.

Meтоды u алгоритмы: Генетический перенос чужеродной ДНК в клетки цианобактерий возможен различными способами: естественным путем [1], электропорацией [2], конъюгацией [3]. Существует также метод трансформации с помощью генной пушки [4], но он не получил широкого применения для трансформации цианобактерий. Кроме того, на данный момент для исследованных цианобактерий не применяются трансдукция, несмотря на изучение различных цианофагов [5], и метод химической трансформации.

Одно из направлений применения цианобактерий - химическое производство. Важной областью химического производства цианобактерий является производство продуктов, которые могут использоваться в качестве биотоплива. Кроме того, получение цианобактериальных штаммов-продуцентов различных предшественников пластика способно снизить потребление источников нефти для производства пластмасс и полимеров. Помимо этого, полученные с помощью модифицированных цианобактерий продукты могут использоваться в фармацевтике, косметической и пищевой промышленности, а также во многих других сферах человеческой жизнедеятельности.

Заключение: Цианобактерии являются привлекательным ресурсом для получения различных промышленно значимых продуктов. Применение модифицированных цианобактерий для производства биотоплива, химических продуктов, продуктов на основе нефти является хорошей «зеленой» альтернативой. Простота способов культивирования и доступность методов геномного редактирования цианобактерий позволяют найти им применение в фармацевтике, косметической и пищевой промышленности, а также для производства многих других необходимых продуктов.

Благодарности: Источник финансирования - Соглашение с Минобрнауки № 07515-2019-1659 от 31.10.2019.

\section{Список литературь}

1. Nies F. et al. PLoS One. 2020;15(6):e0234440.

2. Bruns B.U., Briggs W.R., Grossman A.R. PNAS. 1984;81(5):1561-1565.

3. Takeyama H. et al. Biotechnol. Techniques. 1995;9(5):355-360.

4. Rimon A., Oppenheim A.B. Virol. 1975;64(2):454-463.

5. Hu N.T. et al. Virol. 1981;114(1):236-246. 